\title{
Humerus trochlea aplasia
}

INSERM

\section{Source}

INSERM. (1999). Orphanet: an online rare disease and orphan drug data base. Humerus trochlea aplasia. ORPHA:3383

Humerus trochlea aplasia is an extremely rare familial bone deformity described only in Japanese patients to date. The deformity is bilateral in nearly half of patients (with bilateral involvement, the condition is symmetrical) and sometimes causes ulnar nerve palsy or cubitus varus. 